\title{
MENGHADIRKAN ETIKA KOMUNIKASI DIMEDIA SOSIAL (FACEBOOK)
}

\author{
Muhamad Irhamdi \\ FDK UIN SunanKalijagaYogyakarta \\ irhamsatariah@gmail.com
}

\begin{abstract}
Abstrak
Manusia sebagai makhluk sosial tidak akan pernah bisa lepas dari aktivitas komunikasi penyampai pesan kepada manusia lainnya yaitu antara komunikator dan komunikan. Pengiriman pesan dari komunikator ke komunikan dapat menciptakan feed back yang positif jika etika didalam berkomunikasi menjadi acuan didalam menentukan cara atau pemilihan pesan komunikasi. Di era new media, dimana manusia bisa berkomunikasi tanpa batasan jarak, tempat dan waktu menjadi model komunikasi yang efektif dan efisien dengan memanfaatkan internet sebagai wadah untuk berkomunikasi dimedia sosial secara online. Media sosial seperti facebook merupakan bagiam dari media massa yang bersipat publistik dengan bebas dapat menyampaikan pesanpesan komunikasi tanpa batasan apapun, sehingga berpotensi pada pesan-pesan yang tidak edukatif, informatit dan menghibur. Didalam menggunakan media sosial menghadirkan etika komunikasi pada khlayak komunikan yang sangat heterogen baik dari segi umur, agama, budaya dan kelas-kelas sosial menjadikan etika didalam berkomunikasi menjadi hal yang sangat penting untuk mengantisipas dampak negatif dari penggunaan media sosial facebook.
\end{abstract}

Kata Kunci: Etika, Komunikasi, Kebebasan pesan, Media Sosial. 


\section{A. Pendahuluan}

Kebutuhan manusia sebagai makhluk sosial yaitu kebutuhan untuk terhubung guna berinteraksi satu sama. Media sosial sebagai media untuk berinteraksi dengan cara berkomunikasi di era modern sangat berperan guna untuk memenuhi kebutuhan sebagai makhluk sosial. Media sosial hadir sebaga sarana untuk berbagi ide, opini, informasi, wawasan pengalaman dan bahkan beridiskusi,tidak hanya secara personal bahkan, secara kelompok media sosial dapat memfasilitasi.

Kehadiaran internet sebagai media baru new mediamemiliki perkembangan yang sangat pesat dimasyarakat. Kehadiran internet merubah cara pandang masyarakat didalam berkomunikasi dari komunikasi yang dibatasi dengan jarak, waktu dan ruang menjadi komunikasi yang tak terbatas. Di era internet komunikasi bisa terjadi kapan saja, dimana saja tanpa harus tatap muka sehingga antara komunikator dan komunikan dapat saling meniadakan satus sosial yang terbentuk secara kultural oleh masyarakat dengan batasan-batasan nilai, norma dan kebudayaan yang menjadi identitas bangsa indonesia. Dalam konteks komunikasi, dengan menggunakan media sosial etika komunikasi menjadi hal yang tidak penting lagi dihadirkan di dalam proses komunikai, sehingga tak jarang penggunaan media sosialmenjadi hal yang sangat negatif bagi masyarakat.

Media sosial merupakan media komunikasi yang paling banyak diminati di era modern ini dengan berbagai macam tujuan dan kebutuhan, baik itu kebutuhan bisnis, politik, hiburan, integrasi sosial bahkan propaganda.Media sosial bukan hanya menjadi kebutuhan tetapi, kekininan menggunakan media sosial menjadi sebuah trend untuk menunujuakn diri sebagai individu yang paham akan dunia internet. Media sosial seperti facebook merupakan media dengan konsep komunukasi dua arah sehingga menimbulkan feedback secara langsung dalam bentuk dialog antara komunikator dan komunikan sehingga menimbulkan efek komunikasi.

Media sosial merupakan bagian dari media massa. Istilah "massa" lebih besar dari kelompok, kerumunan atau publik. Para anggotanya tersebar luas dan bisanya tidak sailing mengenal satu sama lain. Masa ditandai oleh komposisi yang selalu berubah dan berada dalam batas diri, tetapi "disetir" untuk 
melakukan suatu tindakan, para anggotanya heterogen dan banyak sekali jumlahnya serta berasal dari semua lapisan sosial dan kelompok demografis. $^{1}$

\section{Penggunaan} facebook sebagai media sosial untuk saling menghubungkan dengan pengguna lainnya baik yang dikenal maupun yang tidak dikenal memiliki dampak dua sisi yang harus dipilih yaitu, sisi integratif sebagai manfaat positif dan sisi disintegratif sebagai efek yang negatif karena akses informasi dimedia facebook tidak hanya mengubungkan penggunanya pada level nasiaonal melainkan juga pada level internasional. Facebook merupakan media sosial online dengan menggunakan akun pribadi tetapi pesan-pesan yang disampaikan oleh pengguna akun facebook tersebut dapat diterima atau diakses oleh siapa saja (massa) dengan latar belakang yang berbeda-beda baik itu latar belakang agama, budaya, afiliasi politik dan bahasa yang sangat heterogen sehingga, pesan yang di update baik dalam bentuk gambar maupun tulisan memiliki penafsiran yang berbeda-beda antara komunikator dan komunikan tersebut.

1 Dennis McQuail, Teori Komunikasi Masa, (Jakarta; Penerbit Erlangga 1996), 32
Didalam pemanfaatan facebook sebagai media komunikasi sosial dalam media massa tentu menghadirkan komunikan yang sangat heterogen sehingga etika dalam berkomunikasi sejatinya menjadi bagian yang sangat penting untukmentransformasikannilai-nilai yang positif didalam menyampaikan pesan-pesan kepada khlayak ramai. Etika tidak hanya berada pada prilaku manusia tetapi juga sangat penting untuk dihadirkan didalam berkomunikasi baik itu komunikasi secara langsung secara tatap muka (face to face) dan komunikasi dengan menggunakan media sosial online. Interaksi yang berlangsung di media sosial harus mengedepankan dampak yang positif bagi komunkator dan komunikan dengan menunujukan nilai-nilai yang etik yang tidak hanya mementingkan diri sendiri tetapi juga memperhatikan komunikan yang sangat beragama sehingga tidak terjadi kesalah pahaman antara komunikator dan komunikan didalam menafsirkan makna pesan dari komunikasi tersebut.

Manusia modern bukanlah sekedar homooeconomicus, tetapi juga homoethicus dan homoreligius. ${ }^{2}$ Nilai-

\begin{tabular}{lrr}
\hline Benny & H. & Hoed, \\
Semiotik\&DinamikaSosialBudaya, & (Komunitas \\
Bambu: Depok,2011), 229. &
\end{tabular}


nilaiyangetis didalamberkomunikasi memnjadi orientasi yang sangat penting bagai manusia sebagai makhluk sosial yang tidak pernah lepas dari aktivitas komunikasi dengan cara verbal ataupun non verbal entah itu dengan komunikasi langsung ataupun dengan menggunakan media sehingga dapat saling menghargai antara individu yang satu dengan lainnya. Pemilihan kata, melihat konteks komunukasi dan memahami lawan komunikasi merupakan bagian yang sangat penting guna tercapainya tujuan komunikasi agar pesan yang disampaikan dapat diterima sehingga dapat mempengaruhi orang lain.

\section{B. Etika Dan Komunikasi}

\section{Etika}

Secara etimologi (bahasa) "etika" berasal dari bahasa Yunani ethos. Dalam bentuk tunggal, "ethos" berarti tempat tinggal yang biasa, padang rumput, kandang, kebiasaan, adat, akhlak, perasaan, cara berfikir. Dalam bentuk jamak, ta etha berarti adat kebiasaan. Dalam kamus besar bahasa indonesia, etika adalah ilmu pengetahuan tentang asas-asas akhlak. Etika dibedakan dalam tiga pengertian pokok, yaitu ilmu tentang apa yang baik dan kewajiban moral, kumpulan asas atau nilai yang berkenaan dengan akhlak, dan nilai mengenai benar dan salah yang dianut satu golongan atau masyarakat. ${ }^{3}$

Dalam ilmu filsafat, etika (ethics) adalah kajian tentang hakikat moral. Etika dapat didefinisikan sebagai "sesuatu yang seharusnya dilakukan atau tidak dilakukan”. Etika merupakan landasan bagi moral. Bila masyarakat atau sekelompok warganya, menganut suatu etika, etika itu menjadi dasar bagi "prinsip-prinsip supra natural" yang mengayomi masyarakat itu. Etika berada dalam hati nurani manusia yang harus mempertimbangkan apa yang "baik" dan apa yang "buruk" didalam interaksi sosial. ${ }^{4}$

Etika merupakan konsep yang sangat abstrak dari kumpulan nilainilai, akhlak dan juga moral yang ada pada setiapindividu dan hadir melalui konsesus bersama atas golongan. Nilai-nilai, akhlak dan moral pada setiap golongan memiliki ketentuan masing-masing yang dibentuk berdasarkan kepentingan golongan itu sendiri sehingga, nilai etik yang dianggap benar oleh golongan tertentu belum tentu menjadi sebuah

3 Muhamad Mufid, Etika Dan Filsafat Komunikasi, (Kencana: Jakarta, 2009), 173.

4 Benny H. Hoed, Semiotik\&DinamikaS osialBudaya..., 230. 
kebenaran yang etis bagi kelompok lain, lebih-lebih di Indonesia yang memiliki keberagaman suku, bahasa dan agama. Istilah nilai menunjuk kesebuah konsep, aturan dan tata cara berperilaku secara kolektif. Etika bisa saja dikatakan sebagai sebuah identitas sebuah golongan yang menjadi fondasi awal untuk menentukan pilihan, perilaku dan tentunya tata cara berkomunikasi.

Komunikasi berasal dari fakta bahwa kelompok-kelompok budaya atau subkultur-subkultur dalam suatu budaya tentu mempunyai perangkat norma yang berlainan. Misalkan terdapat perbedaan dalam norma-norma komunikasi antara kaum militer dengan kaum sipil, kaum abangan dengan kaum santri, kaum konservatif dengan kaum radikal, penduduk kota dengan penduduk desa dan bahkan antara generasi tua dan generasi muda. ${ }^{5}$

\section{Komunikasi}

Komunikasi merupakan aktivitas yang amat penting dan tidak dapat dipisahkan dari kehidupan makhluk di dunia, terutama manusia. Karenanya tidak salah apabila dikatakan bahwa sejarah komunikasi samatuanya dengan sejarah umat

5 Deddy Mulyana, Komunikasi Suatu Pengantar, (PT Remaja Rosdakarya: Bandung, 2009), 7. manusia dan terus ada sampai akhir masa. Begitu pentingnya komunikasi bagi manusia, sehingga ada yang menyatakan bahwa tanpa komunikasi kehidupan manusia tidak akan punya arti atau manusia tidak akan bertahan lama. ${ }^{6}$

Kata komunikasi atau comunication dalam bahasa inggris berasal dari bahasa Latin communis yang berarti "sama", communico, communicatio atau communcare yang berarti membuat sama (to make common). ${ }^{7}$ Cara yang baik untuk meggambarkan komunikasi adalah dengan menjawab pertanyaanpertanyaan berikut, Who Says What In Which Channel To Whom With What Effect, siapa mengatakan apa dengan saluran apa kepada siapa dengan pengaruh bagaimana. $^{8}$ Dari pengertian di atas dapat dipahami komunikasi merupakan proses penyampaian pesan dari komunikator ke komunikan dengan menggunakan beberapa saluran media seperti media massa, media cetak, audio, visual media sosial

6 Mohammad Zamroni, Filsafat Komunikasi: Pengantar Ontologis, Epistemologis, Aksiologis, (Graha Ilmu: Yogyakarta, 2009), 5.

7 Deddy Mulyana, Komunikasi Suatu Pengantar, (PT Remaja Rosdakarya: Bandung, 2009), 46

8 Deddy Mulyana, Komunikasi Suatu Pengantar..,69. 
online bahkan dengan media lukisan. Pemilihan pesan dan saluran media merupakan tentu merupakan pilihan yang sengaja ditentukan untuk mencapai tujuan yang sangat beragam. Dari komunikasi tersebut, baik itu tujauan informatif, hibruran, publikasi bahkan tujuan politik.

Dalam konteks kekinian media komunikasi menjadi sangat beragam, praktis dan efisien, seperti media baru atau New Media merupakan perangkat teknologi komunikasi yang dapat digunakan atau dimanfaatkan kapan saja dan dimana saja dengan ciri digital dan ketersediaannya yang luas untuk penggunaan pribadi sebagai alat komunikasi. Sebagaimana kita lihat "media baru" sangat beragam dan tidak mudah didefinisikan, tetapi kita tertarik melihat media baru pada penerapannya yang dalam berbegai wilayah memasuki ranah komunikasi.mediabaruatau internet yang dapat dimanfaatkan melalui media social facebook, instagram, twitter dan aplikasi-aplikasi media social lainnya memiliki ciri sebagai berikut. Pertama, internet tidak hanya berkaitan dengan dengan produksi dan distribusi pesan, tetapi juga dapat disetarakan dengan pengolahan, pertukaran dan penyimpanan. Kedua, media baru merupakan lembaga komunikasi publik dan juga privat dan diatur dengan layak. Ketiga, kinerja mereka tidak seteratur sebagaimana media massa yang profesional dan birokratis. Hubungan media baru dan media massa menekankan fakta bahwa penyebarannya yang luas secara prinsip tersedia untuk semua jenis komunikasi, dan setidaknya bebas dari kontrol. ${ }^{9}$

\section{Media sosial}

Media sosial hadir sebagai bagian dari perkembangan media baru yang kontras dengan media lama tradisional seperti media cetak dan media audio visual. Perbedaan yang menonjol antara media sosial sebagai mediabarudenganmedialamaantara lain dalam hal kualitas, jangkauan, frekuensi, kegunaan, kedekatan dan sifatnya yang permanen contohnya adalah internet.

Media sosial mengubah pasar media dari komunikasi monologis ke komunikasi dialogis, ini terjadi karena di media sosial menyediakan platform online bagi pengguna untuk perpartisipasi aktif secara ineraktif. Melalui media sosial maka para pengguna dapat berpartisipasi aktif interaktif secara

9 Denis Mc Quail, Teori Komunikasi Massa, (Salemba Humanika: Jakarta, 2011), 150. 
terbuka untuk menyampaikan, menerima dan berdiskusikan. Media sosial merupakan platform yang memungkinkan para pengguna berinteraksi dan berpartisipasi dalam pembuatan konten lalu berkomentar sesuai dengan keberadaan mereka. ${ }^{10}$ Media sosial merupakan bagian dari "media massa" memberikan gambaran mengenai alat komunikasi yang bekerja dalam berbagai skala, mulai dari skala terbatas hingga dapat mencapai dan melibatkan siapa saja dalam masyarakat dalam skala yang sangat luas. Istilah media massa mengacu kepada sejumlah media yang telah ada sejak puluhan tahunlalu tetap digunakan hingga saat ini seperti surat kabar, majalah, film, radio televisi dan internet. Media massa memiliki sifat karakteristik yang mampu menjangkau massa dalam jumlah besar dan luas (universality of reach), bersifat publik dan mampu memberikan popularitas kepada sispa saja yang muncul di media massa. $^{11}$

Kehadiran media social membantu manusia untuk berbagi

10 Alo Liliweri, Komunikasi AntarPersonal, (Prenadamedia Group: Jakarta, 2015), 288.

11 Morissan, Teori Komunikasi Individu Hingga Massa, (Kencana Prenadamedia Group: Jakarta, 2014), 480. prespektif, wawasan, pengalaman dan opini. Partisipasi dari masyarakat pada umumnya telah memberikan dorongan bagi pemenuhan kebutuhan tersebut. Kini hamper tidak ada seorangpun yang tidak berpartisipasi dalam satu atau lebih jenis media social. Ada beberapa karakteristik dari media social pertama, orang mulai berkomunikasi secara dialogis dengan media social sebagai media baru dan mulai mengabaikan komunikasi yang monologis. Kedua, dari segi aplikatif maka media sosial memiliki beberapa karakteristik 1). Meliputi berbagai format konten termasuk teks, video, foto, audio, PDF, powerpoint artnya para pengguna dapat memilih variasi media sosial dalam rangka pembentukan konten. 2), melibatkan berbagai tingkat keterlibatan peserta yang dapat membuat komentar atau mengintai melalui jaringan media sosial. 3) memfasilitasipeningkatan kecepatan dan luasnya penyebaran informasi. 4) menyediakan komunikasi one to one, one to many and many to many. Ketiga,dari segi keunggulan maka media sosial mempunyai karakteristik yang disebut evolusi, revolusi dan kontribusi. Media sosial disebut 1) evolusi karena dia menunjukan perkembangan baru dari cara seseorang berkomunikasi 
misalnya dengan e-mail, 2) revolusi karena untuk pertama kali dalam sejarah komunikaasi, kita semua memiliki akses yang sangat bebas, komunikasi dapat dilakukan secara instan dan mengglobal, 3) sebagai kontribusi karena kehadiran media sosial dapat membedakan kemampuan setiap orang untuk berbagi dan berkontribusi pesan kepada sasran. ${ }^{12}$

\section{Pentingnya Etika Komunikasi Di Media Sosial}

Dalam perspektif komunikasi pertanyaan yang kerap mengemuka adalah sebagai "makhluk bernilai", standar nilai apa yang bisa dipertimbangkan untuk memulai prilaku komunikasi agar bisa meneruskan serta mewujudkan kehidupan umat manusia yang lebih baik disesuaikan dengankarakteristik sentralsifatmanusia?Daripertanyaan di atas memunculkan empat jawaban, pertama, bertindaklah sedemikian untuk memperlakukan umat manusia, apakah atas namamu sendiri atau atas nama orang lain, selalu sebagai tujun dan bukan hanya sebagai cara. Kedua, dalam transasksi komunikasi, kita harus setia kepada "nilai-nilai pembudayaan" seperti

12 Alo Liliweri, Komunikasi AntarPersonal, 289. kebijaksanaan, cinta dan keteraturan. Ketiga, dalam berkomunikasi kita harus menghargai perintah kesopanan. Dalam prilaku verbal ataupun non verbal, kita harus memberikan sikap contoh "dialogis" sejati, terus terang, keramahan, nonposesif, dan seterusnya. Dengan kesopanan berarti kita menghindari setiap praktik komunikasi yang "melanggar nilai hakiki" orang lain. Keempat. "kebutuhan etika akan ketelitian dan kejujuran" adalah hal yang sangat penting. Melalui komunikasi, kita tidak hanya menyampaikan pengetahuan yang sudah mapan, tetapi menciptakan atau membangun pengetahuan. ${ }^{13}$

Didalam menggunakan media sosial seperti facebook sebagai media komunikasi yang bersifat "massa" dengan bernagai macam dimensi sosial budaya maupun agama menghadirkan etika dalam berkomunikasi menjadi suatu keharusan bagi pengguna facebook. Seperti yang telah dijelskan di atas sifat komunikasi sosial dan komunikasi media massa sangat berbeda yaitu komunikasi sosial yang tidak birokratis dan sangat individual memungkinkan tidak

13 Alex sobur, filsafat komunikasi: Tradisi dan Metode Fenomenologi, (Remaja Rosdakarya: Bandung, 2013), 325. 
ada aturan-aturan atau sesuatu yang bersifat evaluatif sebelum mentransmisikan pesan kepada komunikan yang sangat beragam membuat komunikasi sosial melalui facebook berpotensi pada dampak yang sngat negatif, karena facebook merupakan media komunikasi yang memiliki banyak fitur baik itu untuk kebutuhan politis, publikasi dan hiburan dengan menulis status, mengupload foto bahkan video.

Didalam media sosial khususnya facebook banyak sekali dijumpai kata-kata bahkan gambar atau video yang sangat jauh dari kata bermoral. Didalam menggunakan facebook dengan menuliskan status banyak terdapat pro dan kontra tertakit dengan stitmen yang dituliskan pada status tersebut sehingga menghadirkan massa untuk ikut serta dalam mengomentari isi atau pesan yang ada pada media komunikasi tersebut, sehingga perdebatan antar pengguna tidak dapat tertkontrol bahkan sampai pada pertikaian dari medai sosial kepada kehidupan yang rill dengan mengesampingkan nilai-nilai etika dan moral.

Menghadirkan etika didalam semuabentuk dan model komunikasi menjadi sesatu yang penting baik antara komunikator dan komunikan.
Sebagai seorang komunikator agar apa yang disampaikan pada sebuah pesan komunikasi dapat diterima dan dapat merubah perilaku dari komunikan, etika menjadi priritas yang utama agar tidak menimbulkan salah paham antara komunikator dan komunikan. Sebagus dan sangat bermanfaatnya pesan dari komunikasi jika disampaikan dengancara yang tidak sopan, tidak beretika dan jauh dari nila-nilai moral lebih-lebih dimedia sosial yang sangat heterogen akan menjadi sesuatu yang tidak bermanfaat bahkan berpotensi pada sebuah konflik.

Komunikasi sejatinya lebih dari sekedar menolong untuk mengumpulkan informasi atau untuk memenuhi kebutuhan personal. Komunikasi juga berperan didalam menentukan identitas baik secara pribadi, kelompok maupun suatu identitas budaya. Interaksi seseorang dengan dengan yang lainnya menetukan bagaimana sifat seorang manusia. Karena identitas merupakan hal yang sangat penting didalam intraksi komunikasi. ${ }^{14}$ Etika komunikasi di media sosial tidak hanya membentuk atau membangun

14 Larry A. Samovar dkk, Komunikasi Lintas Budaya, (Salemba Humanika: Jakarta, 2010), 17. 
hal yang positif untuk pribadi komunikan melainkan membangun citra yang positif kepada komunitas budaya yang dimiliki bahkan membentuk kesan yang baik bagi agama yang dianut oleh komunikan. Jika komunikasi pada media sosial jauh dari etika dan moral maka komunikan akan perprasngka bahwa komunikator berada pada komunitas budaya bahkan agama yang tidak memiliki nilai-nilai etika dan moral.

\section{Kebebasan Pesan Di Media Sosial}

Media sosial merupakan media yang sangat efektif dan dapat dengan mudah diakses oleh siapa saja tanpa ada batasan-batasan baik dari segi umur, gender bahkan klas sosial. Kebebeasan tersebut bukan hanya pada individu yang menggunakan, tapi kebebasan juga berada pada bagaimana memanfaatkan atau menentukan konten-konten dari isi pesan komunikasi yang disampaikan oleh komunikator dan isi pesanyang diterima oleh komunkan. Media sosialkuususnyaFacebookmerupakan salah satu aplikasi media online sebagai media komunikasi yang sifatnya publistik tidak memiliki batasan baik dalam pennggunaan ataupun pemanfaatannya sehingga dapat dijumpai banyak pesan- pesan komunikasi seperti kata-kata kasar atau kata-kata yang tak layak disampaikan jika dilihat dari kaca mata etika dan moral. Selain itu banyak gambar-gambar dan video yang di upload di beranda facebook yang memperlihatkan auratbaik lakilaki ataupun perempuan sehingga mengandung muatan pesan yang masuk dalam kategori pornografi.

Dalam filsafat, pengertian kebebasan adalah kemampuan manusia untuk menentukan dirinya sendiri. Kebebasan lebih bermakna positif dan ia ada sebagai konsekuensi dari adanya potensi manusia untuk dapat berfikir dan berkehendak. Sudah menjadi kodrat manusia untuk menjadi makhluk yang memiliki kebebsan, bebas unutk berfikir, berkehendak dan berbuat. Kebebasan dan tanggung jawab muatan pesan dimedia sosial sebagai etika komunikasi kadangkala masih bersifat kontradiktif dalam impelmentasinya. Padahal kedua norma tersebut tidaklah bersifat kontradiktif karenanya salah satu harus dipilih untuk kemudian meninggalkan yang lainnya, akan tetapi lebih sebgaia sinkronisasi. Dengan kata lian, kebebasan bukanlah lawan dari tanggung jawab, begitu sebaliknya. Seseorangtidak akankehilangan kebebasannya hanya 
karena ia menerapkan tanggumg jawab. ${ }^{15}$

Media sosial (facebook) menyediakan ruang bagi pengguna untuk menyampaikan pesan komunikasi kepada khlayak ramai dengan konten-konten yang tanpa batas bagi penggunanya. Peran etika komunikasi tidak hanya pada level komunikasi verbal ataupun komunikasi antarpersonal melainkan yang paling penting adalah menghadirkan etika komunikasi pada penggunaan media sosial sebagai media komunikasi yang sifatnya publistik dengan mengedepankan nilai moral yang bersifat informatif dan edukatif dan sepatutnya menghindari pesanpesan komunikasi di media sosial yang bersifat provokatif, porno ataupun menuliskan kata-kata kasar yang sangat tidak mendidik bagi penerima pesan. Kebebdasan dalam menggunakan media sosial (facebook) bukan berarti bebas tanpa batas melainkan harus bersamaan dan tidak bersebrangan dengan nilai-nilai dasar negara yang menjadi acuan didalam berbangsa dan bernegara yaitu acuan pada kata "ketuhana", "bijaksana" dan "beradab".

15 Muhamad Mufid, Etika Dan Filsafat Komunikasi..., 243.
Dengan menggunakan media sosial (facebook) manusia dapat bercerita tentang dirinya atau tentang apapun dengan akses yang sangat cepat yaitu dalam beberapa saat, tanpa dibatasi oleh jarak dan waktu seperi layaknya komunikasi verbal, sehingga dapat ditemuakn berbagai macam konten-konten pesan komunikasi. Hasrat manusia didalam menggunakan media sosial (facebook) sebagai alat publikasi pesan-pesan komunikasi didasari oleh manusia itu sendiri adalah homo naras, alias makhluk pencerita. ${ }^{16}$

Ada beberapa batasan-batasan moral didalam berkomunikasi secara verbal ataupun pada saat menggunakan media sosial sebagai media komunikasi. Pertentangan antara impelmentasi kebebasan dan tanggung jawab sosial dapat diselesaikan melalui pencarian prinsip yang berfungsi sebagai batasan impelmentasi kebebasan, setidaknya ada empat perinsip yang harus dipahami, yakni:

1. Harmprinciple

Menurut prinsip ini kebebasan individu layak dibatasi untuk mencegah terjdinya tindakan menyakiti orang lain.

16 Gun-Gun Heryanto, Problematika Komunikasi Politik, (IRCiSoD: Yogyakarta, 2018), 363. 
2. Paternalismprinciple

Menurut prinsip ini media sangat berpengaruh terhadap masyarakat. Seperti istilah "we are what we read/view". Kita menjadi apa yang kita baca/ tonton. Karenanya muatan pesan media haris dikontrl sedemikian rupa sehingga hal-hal cabul atau yang merugikan masyarakat dapat dicegah.

3. Moralismprinciple

Menurut prinsip ini baik tidaknya moral ditentukan oleh masyarakat, bukan oleh individu. Karenanya kebaikan individu tidak akan berarti bila kemudian masyarakat mengatakannya sebagai keburukan, begitu juga sebaliknya.

4. Offenseprinciple

Menurut prinsip ini penyampaian pesan tidak boleh menimbulkan rasa malu, kegeliasahan dan kebingungan bagi orang lain. ${ }^{17}$

Informasi dalam sebuah pesan komunikasi sangat berkaitan dengan kualitas pengirim kepada penerima kepada satu atau lebih peneriam. Informasi atau pesan selalu memiliki parameter, tentang adanya peristiwa,

17 Muhamad Mufid, Etika Dan Filsafat Komunikasi.., 255. niliadanetika. ${ }^{18}$ Daripenjelasandiatas tentang hakikat dari pesan informasi dapat dipahami bahwa setiap pesan yang disampaikan dengan model komunikasi apapun merupakan cerminan dari karakteristik sebuah kebudayaan yang ditempati oleh pelaku komunikasi, dalal arti bahwa ketika komunikator menyampaika konten-konten pesan pada sebuah aktivitas komunikasi berpotensi negatif seperti kata-kata kasar, ujaran kebencian atau berita bohong maka secara otomatis komunikan atau penerima pesan baik dengan menggunakan media sosial atau model komunikasi face to face berasumsi bahwa keberadaan atau karakter pesan komunikator mencerminkan identitas diri, karena pada dasranya lingkungan merupakan bagian utama dalam membentuk kepribadian seseorang dan komunikasi merupakan cerminan dari latar belakang budaya bahkan agama yang dimiliki oleh seseorang.

Dari beberapa batasan-batsan moral tersebut mengisyaratkan bahwa melakukan aktifitas komunikasi terlebih komunikasi sosial dengan menggunakan aplikasi

18 Alo Liliweri, Komunikasi Serba Ada Serba Makna, (Prenada Media Group: Jakarta 2011), 839. 
facebook merupakan komunikasi yang sangat kuat memiliki potensi yang negatif tetapi pada sisi lain juga memiliki potensi yang luas secara positif jika, tata cara menetukan pesan ataupu konten didalam media sosial mengedepankan nilia-nilai etis dan moralitas yang ada sebagai sebuah jembatan untuk tercapainya sebuah tujuan komunikasi, sehingga media sosial menjadi media yang sangat efektif dan efisen didalam melakukan aktifitas komunikasi yang tidak terbatas oleh jarak, ruangg dan waktu.

\section{E. Penutup}

Media sosial facebook merupakan bagian dari new media yang dapat diakses melalui internet sebagai media komunikasi yang bersifat publistik dan mempunyai komunikan yang sangat heterogen dan dapat megakses pesan atau konten-konten komunikasi melalui saluran media sosial yaitu facebook. Penggunaan media sosial seperti facebook untuk melakukan aktifitas komunikasi baik dengan tujuan publikasi, informatif ataupun hiburan etika komunikasi menjadi hal yang sangat penting didalam menggunakanfacebook sebagaimedia komunikasi karena tidak mimiliki batasan dalam menentukan pesan komunikasi kemudian diterima oleh komunikasn yang sangat heterogen baik dari sisi agama, budaya, umur bahkan kelas sosial. Etika didalam menggunakan media sosial menjadi ukuran agar tidak menyampaikan pesan-pesan yang bersifat provokatif ataupun pesan-pesan yang berpotensi yang menimbulkan perpecahan antar sesama, terlebih indonesia merupakan negara yang masyrakatnya sangat beragam. Etika komunikasi menjadi acuan yang utama bagi individu didalam menggunakan media sosial yang tidak memiliki batasan jarak dan waktu antara komunikator dan komunikan untuk dapat saling bertukar informasidan setiap komunitas kebudayaan bahkan agama memiliki standar etik yang berbeda-beda sehingga apabila etika didalam berkomunikasi tidak dijadikan hal yang sangat penting didalam menggunakan media sosial maka potensi-potensi konflik seperti perpecahan, kebencian bahkan perperangan menjadi dampak dari penggunaan media sosial yang tidak baik. 


\section{Daftar Pustaka}

Heryanto,Gun-Gun, Problrmatika

Komunikasi Politik,(Yogyakarta:

IRCiSoD, 2018)

, Benny H. Semiotik\& Dinamika Sosial

Budaya, Komunitas, (Depok:

Bambu, 2011)

Liliweri,Alex sobur, filsafat komunikasi: Tradisi dan Metode fenomenologi,(Bandung: Remaja Rosdakarya, 2013)

Liliweri,Alo,Komunikasi AntarPersonal, (Jakarta: Prenada media Group,2015)

Liliweri,Alo,Komunikasi Serba Ada Serba Makna, (Jakarta: Prenada Media Group, 2011)
McQuail,Dennis Teori Komunikasi Masa, (Jakarta; Penerbit Erlangga 1996)

Morissan, Teori Komunikasi Individu Hingga Massa, (Jakarta, Kencana Prenadamedia Group, 2014)

Mufid, Muhamad, Etika Dan Filsafat Komunikasi, (Jakarta, Kencana, 2000)

Mulyana, Deddy Komunikasi Suatu Pengantar, (Bandung: PT Remaja Rosdakarya, 2009)

Samovar dkk, Larry A. Komunikasi Lintas Budaya, (Jakarta: Salemba Humanika, 2010)

Zamroni, Mohammad, Filsafat Komunikasi:Pengantar Ontologis, Epistemologis, Aksiologis, (Yogyakarta:GrahaIlmu, 2009) 